\title{
Planned One-Company Towns and Unplanned Allegiances
}

\author{
ARNOLD R.ALANEN, Morgan Park: Duluth, U.S. Steel, and the Forging of a Company Town. Minneapolis: \\ University of Minnesota Press, 2007. \\ DAVID ROBERTSON, Hard As the Rock Itself: Place and Identity in the American Mining Town. Boulder: \\ The University Press of Colorado, 2006.
}

The interest in planned company towns among urban planners is understandable. These towns represent an essential component of the evolution of the planning discipline. The negative impact of the industrial revolution on health and well-being in industrial cities led to enabling legislation allowing control of the public domain of the city and making house design conform to safety guidelines delineated in building bylaws. Scrutiny of planned one-industry towns - of their evolution and design - provide an understanding of the ways in which the private corporate sector and the capitalist class sought to harness the physical domain of the urban form so as to increase industry profits. But it is the changing meaning of these places for their residents, over the ups and downs of the dominant industry, that emerges as the theme in the two books reviewed here. The cases described illustrate that the economic viability of the industry shapes the lives of town residents who are dependent on it for their livelihood and the well-being of their families. The two books demonstrate the ways in which company town residents are subject to at times capricious rules and regulations of the industry that plans, governs, and regulates not only the physical spaces of the community but also, directly and indirectly, the conduct of its residents.

In the introduction to Morgan Park, Alanen traces the evolution of U.S. model company towns. Beginning in the 1800s, young, single women textile workers were recruited first to small mill villages and then to larger towns and cities in New England. There they were provided a range of highly regulated programs and services and subjected to industrial discipline. The most famous of these towns, Lowell Massachusetts, founded in 1812, exemplified this New England paternalism. From the 1860 s, with greater industrialization, new company towns were developed in several parts of the country. Pullman, Illinois, was conceptualized and developed to mitigate labor unrest. But the heavy-handed regulations, high rents, and wage reductions that were applied are attributed as causal in labor strikes in the Pullman factory in 1894. In reaction, Alanen explains, other industrialists departed from the traditional paternalism of these early experiments. Later company towns such as Gary, Indiana, east of Chicago, despite their stated interest in improving workers' living conditions, differed very little from the speculative plats of nineteenth-century town promoters and real-estate developers who aimed to maximize profits.

In the 1890s and early 1900 s, a period of welfare capitalism followed in which industrial betterment programs to improve the plight of employees were proposed by reformers. The construction of Morgan Park, by U.S. Steel in Duluth, Minnesota, is one example of the planned, designed, model company towns that emerged. Alanen's book, replete with illustrations and detailed descriptions, provides a detailed case of the physical development of Morgan Park, by way of early schematics, public notices and advertisements, initial plans, house prototypes and 
details, and dormitory and administrative building layouts. Photographs of on-site housing construction and the detailing of materials and social and communal activity in these environments flesh out the picture and provide political and strategic context. The descriptions of life in Morgan Park between 1916 and 1930 serve to illustrate the contours of what the "good life" was like in a highly managed and supervised model company town. Through meticulous collection and reproduction of historic photographs, the built form and shape of this model town are made accessible to readers and give a concrete tangibility to the description of the lived life.

The fate of Morgan Park through the depression of the thirties, of limited work and empty houses, is underscored poignantly by a photograph of an automobile service station whose caption states that it was the only major new building that emerged in Morgan Park during the decade of the Great Depression. This was the end of corporate control. By mid-decade, nonsteel-plant employees were allowed to rent Morgan Park housing. Plans to sell the houses, the modification and elimination of many services and employee-benefits, and eventually the turning over, following protracted negotiations, of the town's deed to a reluctant City of Duluth marked the end of that particular brand of corporate paternalism.

The war created job opportunities for entry of women into the labor force. Widowed women with children to raise undertook arduous work in the foundries and ovens of the steel mill. And the process of shifting ownership of homes in Morgan Park to private ownership continued. By the end of 1945, the transition of Morgan Park from company town to a typical neighborhood of Duluth was virtually complete. The detailed documentation of the contestation around this transfer, the advertisements of the real-estate company that purchased Morgan Park holdings and then sold the houses and buildings to individual buyers, illustrates tangibly the end of an economic experiment and its social reality. The Inland Steel plant in Duluth closed in 1971. Alanen describes the swallowing up of the company town identity and the more recent grassroots movements to preserve and restore it. He concludes, "Morgan Park persists, tenaciously so, as a pleasant, appealing, and viable community, as well as a remnant of America's rapidly disappearing industrial heritage" (p. 298).

The meaning of identity derived from place is addressed in David Robertson's book Hard As the Rock Itself: Place and Identity in the American Mining Town. Three case studies of mining towns, single-industry communities dependent on the extraction of nonrenewable resources and involving the creation of troubled environmental landscapes, are described. Mining towns often fail to survive deindustrialization and succumb to wholesale abandonment and ruin. These three cases, however, are of mining communities that outlast their industrial usefulness. They illustrate what that residual landscape and place is worth to their residents. Toluca, Illinois, and Cokedale, Colorado, were coke mining towns, the latter a company town owned and operated by a single firm. Picher, Oklahoma, was a hard rock mining settlement producing lead and zinc. Today Toluca's economy fares relatively well on light manufacture and agriculture but its residents have not forgotten their mining past. Two mounds of coal mining residue, affectionately named "the Jumbos," have elicited a successful rally for their protection. Cokedale, designated a National Historic District in 1985 and one of the country's best-preserved company coal mining towns, reveals only the utopian version, not the gritty reality of its mining past. In Picher, mining-related, devastatingly severe, environmental problems threaten residents' health and existence. Designated an EPA Superfund site in the early 1980s, yet even in its blighted landscape, many retain a deep attachment to the land and the place. For the current residents of all three towns, each with very different quality of life and prognosis for the future, a sense of place and identity remains intimately tied to location and the mining industry continues to give meaning and identity. Affiliation, it appears, is not contingent on aesthetics and quality environment. The details of each town's past underscores this observation.

Coal production in Toluca, spanning 31 years, peaked in 1905 and the mine closed in 1924. In 1900, some 40 percent of the miners were foreign-born, of whom Italians were the majority. 
Although marginalized by the Anglo majority, class mobility proved possible and Italians held prominent positions in the community. During its 31-year history, on an average the mine produced 250,000 tons of coal per year and employed 600 workers, closing in 1924 following a decline in the price of coal after World War I. During the mining years, Toluca is described by outsiders as an "unadorned, ephemeral, and typically wild mining boomtown" (p. 35). Resident accounts paint a more complex picture that includes everyday memories of community life and valued home. When the mines closed, residents faced the difficult decision of choosing between a livelihood and home, and many chose home. The company sold houses it owned to its workers several months prior to announcing closure. Many of these houses caused hardship to workers who bought them and then lost their livelihood. Historic accounts state that Toluca lost twothirds to three-quarters of its population in the year following the closing of the mine. Those who stayed were apparently unwilling to abandon their town. The productive fertile black soil offered a means for survival not only to farmers but also to town residents as their house plats included enough land for a large vegetable garden and fruit and nut trees. By 2000 the local economy had diversified. Agriculture remained a mainstay but the town had an Italian frozen foods factory that had evolved from two Italian bars dating back to the thirties which became popular Italian restaurants. Garment, window, and sporting equipment manufacturing also developed.

The visible signs of Toluca's mining past are the Jumbos, two elongated conical mounds, the larger some 110 feet high consisting of mine glob. Visible throughout the community and from many miles distant they are the town's most notable landscape feature. Movements to save the Jumbos started in 1985, and by the late 1990s an organization was formed to protect these two piles of industrial waste. Robertson observes that the Jumbos have become a landmark setting the town off as different from the rest. A reclamation plan was submitted to the Department of Natural Resources in 1986 and the work was completed in 2000 with tremendous community support, receiving a historical marker in 2001 that celebrates the mining heritage that they represent.

Cokedale built in 1907 to supply coal to American Smelting and Refining Company's (ASARCO's) copper smelting operation in El Paso, Texas, was carefully planned. Situated on the slopes of a canyon, three rows of houses established a hierarchy of residents, the higher-elevation northern street for managers and professional-class employees. Robertson describes the architecture consisting of cinder-block or wood-frame cottages from one- to four-bedroom size, equipped with coal-burning stoves and electricity. Houses were uniform, with hipped or pyramid roofs and stucco walls. Public buildings, including a bath house, were also constructed by ASARCO, and residential areas were separated from the mining operations at the southern end of the town. Cokedale was a state-of-the-art industrial settlement guided by the belief that expenditures in ideal town infrastructure would prove to be wise investments to increase worker productivity and subvert labor unrest. But Robertson points out that Cokedale was no exception to division and conflict along ethnic lines. In 1920 there were no African American residents and the town had an active chapter of the Ku Klux Klan. Census schedules from 1920 reveal that the 142 homes in the community sheltered Anglo-Americans (48), Hispanics (33), Italians (24), Mexicans (23), and others. Eighty percent of the larger homes in the higher-elevation, prestigious part of town were inhabited by Anglo-Americans. ASARCO controlled housing and job assignments, and segregation along class lines was intentional.

Five days after the closing of the mine in 1947, ASARCO sold its property to a salvaging firm that pulled up and sold the towns municipal water pipes and demolished twenty of the twostorey multiple-housing structures. As Cokedale was well connected by road to the nearby city of Trinidad, homebuyers existed. The salvage firm determined that more money could be earned by selling the remaining housing rather than demolishing it. It served as landlord for almost forty years, selling the last property in the 1980s. The 1950s and 1960s were not kind to Cokedale, its infrastructure was in decay and the town council struggled to maintain services on meager property tax revenue. Political power remained with the more affluent "north-siders" who came to be 
known as the "old guard." Robertson observes that the negative legacy of the mining eracompany paternalism, community factions, and a boom-and-bust mining economy - had a lasting influence. For old timers, continuity with a past way of life was more important than community rejuvenation. Refusing to change the town's physical character, they served to preserve the town's historic integrity and identity. The settlements' physical and cultural uniqueness served as the foundation for preservation efforts in the 1980s and 1990s. In 1985, a National Register Nomination was submitted for the community structures (most of which were still standing), some industrial structures and the portion of the housing stock that survived, which Johnson notes was primarily the housing of the well-to-do. A utopian narrative dominates interpretations of Cokedale's past, reinforced by what remains intact and standing - substantial community structures and comfortable homes. What is missing is the social history and the hardships residents faced in the mining era and beyond. These were physically evident in the industrial areas of the community and former shared housing that have since been demolished.

In 1983 Picher, Oklahoma, was placed on the EPA initial list of Superfund sites. More than two decades later, many of its environmental hazards remain uncontrolled. Lead and zinc ore was discovered in the region in 1914, and in three years a boom town of 20,000 emerged. The intrusive nature of industrial development, lack of basic civic amenities, and makeshift construction indicated that this was a despoiled place. Residential and industrial development occurred side by side in Picher. As early as 1890, small quantities of lead and zinc were mined from what would later be known as Picher Field. By 1914, four mines were in operation on land assembled through 40-acre mineral leases from the Bureau of Indian Affairs, and these sections were subleased to workers and merchants for housing and commercial purposes. These leases could be terminated with thirty days' notice. These short leases were not conducive to a rational planning process that would lead to the creation of model towns and efforts to protect public health. Growth of Picher was haphazard. Most residents lived in small drafty dirt-floored shanties adjacent to the mines. Houses were often moved to make way for new or expanding mines, further reducing the incentive to construct substantial housing. Industry invested little wealth in the community, low wages were chronic, and dust-induced respiratory diseases such as tuberculosis were prevalent. By 1930, Picher was a vital community consisting almost exclusively of workers of Anglo descent. The Ku Klux Klan was influential in local politics and succeeded in barring foreign-born Europeans and African Americans from living and working in the region.

In 1958, the last large-scale commercial mine in the Picher field closed. Deindustrialization left behind decayed town infrastructure, described by Johnson (p. 122) as follows: "[There are] the remains of mines and ore mills with their giant piles of grey-colored mining waste, locally known as chat. Streets wind around the mountains of debris, many of which stand more than 200 feet tall, and houses huddle beneath their slopes. Mining has ravaged the environment and left poverty in its wake." Water pollution persists and in the mid-1990s it was discovered that the community had the highest incidence of juvenile lead poisoning in the nation. Chat piles that had long served as playgrounds for children were identified as the source of lead contamination. The landscape Picher inhabitants lived in was detrimental to their health, and although many wanted to leave a substantial number refused to consider relocation because of the emotional bonds they had to the place.

A distinct aspect of the Tri-State Mining District of Oklahoma, Kansas, and Missouri in which the Picher Field is located is that its workers were a relatively homogeneous local labor force, coming from adjacent Ozark Mountain territory. U.S.-born whites accounted for approximately $98 \%$ of the district's population. Tri-State mining towns were known as "white man's camps," and a xenophobic attitude prevailed among its native-born miners. Much of the field lay on Indian land and hence land tenure was complex. Community identity derived from 
residents' ability to survive and thrive in an unforgiving environment. County historian Nieberding characterizes local pride in being "hard as the rock itself" (p. 145).

Living conditions in Picher had worsened by the 1980s. The community failed to diversify its economy and jobs were scarce. City taxes were the highest in the state and needed to address chronic budget deficits. There were formidable environmental issues derived from lead-laden chat piles and acid mine drainage into the waterways. EPA remediation plans attempted to address the contamination issues and a restoration act passed in 2003 funded the relocation of families outside the region of lead contamination. But the voluntary buyout plan was accepted by only a few. Memories and economics kept people in place. Self-respect was derived from the realization that they were survivors.

The case studies presented in these two books of one-industry company towns reveal that the value of a place is not just tied to its aesthetic attributes or to the physical or economic support a place provides. They underscore that attachment of people to place is about more. It is dependent on meaning, association, memory, tenure, relationships, and a powerful hold of the past. These attachments exist in despoiled and in model environments. This observation must serve to make planners pause and give cause for reflection and humility as they attempt to help residents establish roots, community, and identity in the urban places they seek to improve and revitalize. 